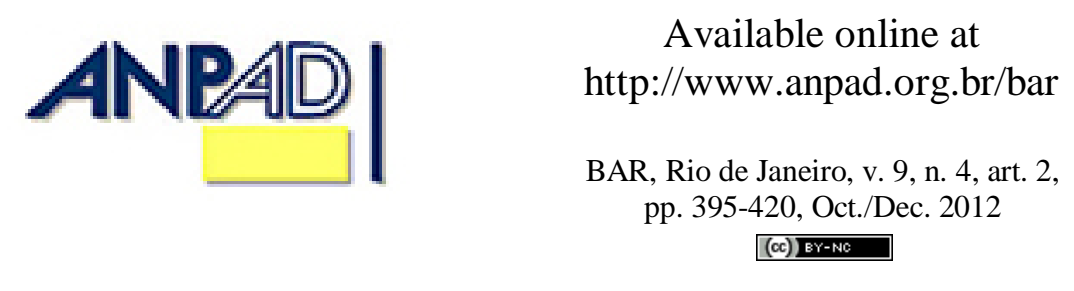

\title{
Human Resources Management Policies and Practices Scale (HRMPPS): Exploratory and Confirmatory Factor Analysis
}

\author{
Gisela Demo * \\ E-mail address: giselademo@gmail.com \\ UCLA Anderson School of Management - University of California \\ Los Angeles, USA. \\ Elaine Rabelo Neiva \\ E-mail address: elaine_neiva@uol.com.br \\ Universidade de Brasília - UnB \\ Brasília, DF, Brazil. \\ Iara Nunes \\ E-mail address: iara.nunes.iara@gmail.com \\ Universidade de Brasília - UnB \\ Brasília, DF, Brazil. \\ Kesia Rozzett \\ E-mail address: kesiaro@gmail.com \\ Universidade de Brasília - UnB \\ Brasília, DF, Brazil.
}

* Corresponding author: Gisela Demo

UnB - Departamento de Administração, Campus Universitário Darcy Ribeiro, ICC Ala Norte, Bloco B - $1^{\circ}$ Andar, Sala 576, Brasília, DF, 70910-900, Brazil. 


\begin{abstract}
Given the strategic relevance of Human Resources Management (HRM) in organizations and the lack of scientific instruments to measure employees' perceptions about policies and practices of HRM, this study aimed to validate the Human Resources Management Policies and Practices Scale (HRMPPS) through exploratory and confirmatory factor analysis using the maximum likelihood method. The study has a quantitative design, but also included qualitative analysis required for the development of a scale. Employees from various organizations composed a sample of 632 people. Scale reliability was assessed by Cronbach's alpha and Jöreskog's rho. A sixfactor model was generated showing high-reliability and good fit. Construct validity was provided through convergent and discriminant analyses. The factors were consistent with the literature review and explained about $58 \%$ of the construct's total variance. This study contributes to the scientific production in the area of Human Resources Management since HRMPPS can be used not only in relational studies but also as an evaluation instrument by managers who wish to improve their employees' well-being as well as organizational outcomes.
\end{abstract}

Key words: human resources policies; exploratory factor analysis; confirmatory factor analysis; structural equation modeling. 


\section{Introduction}

Given the strategic relevance of Human Resources Management (HRM) in organizations and the lack of scientific instruments to measure employees' perceptions about policies and practices of HRM, the objective of this study is to develop and validate a Human Resource Management Policies and Practices Scale, called HRMPPS.

According to Huselid (1995), work on the measurement of HRM policies and practices is extremely limited and this is still true today. Besides some indexes of HRM practices identified by advocates of the high commitment approach (Guest, 1998; Pfeffer, 2005), the only scales found in the literature were the High-Performance Work Practices developed and validated by Huselid (1995), with 13 items and a .67 Cronbach's alpha, and the Perception of Personnel Management Policies Scale (PPMPS), developed and validated by Demo (2008), with 19 items distributed across 4 factors and presenting Cronbach's alpha above .70 .

The PPMPS includes only four HRM policies: involvement; training, development and education; work conditions; and compensation and rewards. Considering the shortage of scientific validated scales to measure employee's perceptions about HRM policies, the PPMPS is a good option to be used so far (e.g. Rubino, Demo, \& Traldi, 2011). However comprehensive instruments with higher reliability for measuring HRM policies and practices are demanded.

Thereafter, this paper attempted to answer the following question: is it possible to develop and validate a comprehensive and highly-reliable scale, validated through both exploratory and confirmatory factor analysis?

The HRMPPS presented here sought to improve the completeness and the scope of the previous scales validated in the literature by adding policies for recruitment and selection, competency-based performance appraisal, also often cited by classic authors of the area, such as Bohlander and Snell (2009), Dessler (2002), Guest (1987), Sisson (1994) and Storey (1995).

Furthermore, if the HRMPPS presents good psychometric parameters, remaining stable in other samples, it would be a reliable and more comprehensive instrument than the existing ones for use in relational studies in the Human Resources, Management and Organizations fields. Additionally, it can be used in managerial practice as well, as a diagnosis to improve employee's well-being at work and optimize organizational results.

First, a literature review is presented about human resources management, its strategic role in organizations, and human resources management policies, including their constitutive definitions. The methods used are then described, detailing the procedures to develop the scale, the exploratory validation, the validation in a different sample in order to test the scale generalizability and the confirmatory factor validation through structural equation modeling. Construct validity is provided through convergent and discriminant analysis. Finally, the results are presented and discussed and conclusions are made, focusing on the study contributions and proposal of a research agenda.

\section{Theoretical Background}

Many authors understand HRM's current role in the organizations as being strategic. One of the distinctive features of HRM is that better performance is achieved through the people in the organization (AlDamoe, Yazam, \& Ahmid, 2012). Ulrich, Halbrook, Meder, Stuchlik, and Thorpe (1991) stated that the competitive panorama is constantly being changed and has been demanding new models of competitiveness which in turn require organizational capacities that will enable the companies to better serve their customers and distinguish them from their competitors. These 
organizational capacities come from the redefinition and redistribution of HRM practices, functions and professionals.

By summarizing what authors such as Guest (1987), Storey (1995), Legge (2006) and Bohlander and Snell (2009) say, it is possible to observe that people have been assuming a strategic and relevant role in organizations, and therefore cohesive and coherent theories - aligned to both planning and organizational strategy - must properly sustain HRM.

In this meaning, HRM policies and practices may vary among organizations and should be aligned with business strategy (Chênevert \& Tremblay, 2009). Boxall and Purcell (2000) add that the effects of individual HRM practices depend on both the nature of the effects of other HRM practices and the business strategy. Also, Lim (2012) argues that external business environment has a strong influence on HRM activities.

From the perspective of Strategic HRM, policies and practices can be mutually reinforced and create a strong impact on organizational goals (Morris \& Snell, 2010). Moreover, HRM policies are guided by the logic of skills developed in accordance to the requirements of business processes (Serpell \& Ferrada, 2007). Thus, they provide tools to capture and communicate the strategic vision and objectives of the organization in clear terms that can be more easily understood and requested (Vakola, Soderquist, \& Pratascos, 2007).

Within this context, the development of scales that allow an estimation of the perception of HRM policies aims to identify to what extent they are applicable to various organizations and aligned with an organization's strategy. In addition, a scale can translate how HRM policies are associated with business strategy, because only then can they be effective (Legge, 2006).

HRM must also not be relegated to a traditional supporting role anymore, but instead must constitute an essential competence in reaching the organizational and individual objectives and results, since human resources are valuable and constitute a source of competitive advantage. Uysal (2012) indeed found strong, positive and significant correlations among the main HRM policies cited in the literature, such as staffing, training, performance evaluation and compensation. These results are important for understanding the inter-relationships between HRM practices in order to enhance the effect HR systems have on employee-based organizational outcomes.

In this context, organizations have turned to the perspective of creating competitive advantage. Consequently, themes related to the areas of organizational strategy and theory converge, spawning comprehensive implications for HRM and putting its primary function under discussion. According to the Resourced Based View by Barney (1991), the creation of competitive advantage depends on prerequisites that may be closely related to the HRM area, since resources must be valuable and rare to the organization, may never be imitated or replaced, and the organization must be able to exploit them. Beauvallet and Houy (2010) support that the key mechanism and decisive variable that would justify the competitive advantages of companies alleged as being lean enterprises, or the ones practicing a lean management, are directly related to HRM.

The term organizational policy can be defined as: principles established for leading a company, a general course of action in which some practices are developed collectively, in a constructive way, aiming to reach certain objectives (Singar \& Ramsden, 1972). HRM policies define the attitude, expectations and values of the organization concerning how individuals are treated, and still serve as point of reference for the development of organizational practices and for decisions made by people, besides resulting in equal treatment among individuals (Armstrong, 2009).

In this study the term HRM policy means an organizationally articulated proposal, with theoretical and practical constructions within human relations aiming to reach the desired results. Thereby, HRM policies define theoretical and practical referential built to make possible the reaching of an organization's objectives and purposes, operating as thinking and acting guides for the HRM area. 
Some research results have pointed out positives relationships between HRM policies and variables like commitment, productivity, profitability and quality, among others (Guest, 1987; Schneider \& Bowen, 1985; Ulrich, Halbrook, Meder, Stuchlik, \& Thorpe, 1991). In the meta-analysis performed, Combs, Liu, Hall, and Ketchen (2006), found that relationships between Human Resources practices and organizational outcomes are stronger in manufacturing companies than in service companies.

Studies have also been conducted in cultures other than the American and European ones. Majumder (2012) verified strong relationships between HRM practices and employee satisfaction in Bangladeshi private banks, and Kim and Lee (2012) found evidence that HRM policies and practices improve strategic capabilities and firm performance in management consultant firms in South Korea. The study by Demo (2010) showed positive and strong relationship between HRM policies and organizational justice in both private and public Brazilian organizations.

Similarly, other researches have shown that HRM policies and practices favorably affect organizational performance (Boselie, Dietz, \& Boon, 2005; Menezes, Wood, \& Geladi, 2010; Subramony, 2009). Guest and Conway (2011) confirmed the association between both more HRM practices and higher HR effectiveness and a range of performance outcomes.

Besides, ALDamoe, Yazam and Ahmid (2012) concluded that employee retention is likely to mediate in the relationship between HRM practices and organizational performance. Employee perceptions of HRM policies and practices also influence discretionary work effort and co-worker assistance (Frenkel, Restubog, \& Bednall, 2012). On the other hand, the effectiveness and acceptance of HRM policies are related to organizational values and culture (Stone, Stone-Romero, \& Lukaszewski, 2007).

There is indeed a consensus that HRM practices produce higher organizational performance when integrated into business strategy (Ezzamel, Lilley, \& Willmott, 1996; Guest \& Hoque, 1994). This is also true for small firms. The study conducted by Katou (2012) showed that HRM policies have a positive effect on organizational performance through employee attitudes (satisfaction, commitment, motivation) and employee behaviors (absences, turnover, disputes).

In summary, HRM policies assume special connotation in development, appreciation and retention of talents. They also promote employee commitment and, as a result, goodwill on their part to act in a flexible and adaptive manner towards excellence in organizations (Legge, 2006). An entrepreneurial strategy aiming at production and supply of added-value products and services must concern the development and the implementation of HRM policies resulting in well-qualified employees (Legge, 2006).

Table 1 summarizes the selected policies as well as constitutive definitions elaborated from the literature review. The main authors who were reviewed in the development of the theoretical background for each HRM policy are pointed out.

Table 1

\section{Constitutive Definitions of HRM Policies and Their Theoretical Backgrounds}

\section{HRM Policy Constitutive Definition and Authors Reviewed}

Recruitment Organizationally articulated proposal, with theoretical and practical constructions, to look for and Selection employees, encourage them to apply, and select them, aiming to harmonize people's values, (RS) interests, expectations and competences with the characteristics and demands of the position and the organization.

Authors reviewed: Armstrong (2009); Bohlander and Snell (2009); Dessler (2002); Lievens and Chapman (2010); Mathis and Jackson (2003). 


\section{Table 1 (continued)}

\begin{tabular}{|c|c|}
\hline HRM Policy & Constitutive Definition and Authors Reviewed \\
\hline \multirow[t]{2}{*}{$\begin{array}{l}\text { Involvement } \\
\text { (I) }\end{array}$} & $\begin{array}{l}\text { Organizationally articulated proposal, with theoretical and practical constructions, to create an } \\
\text { affective bond with its employees, contributing to their well-being at work, in terms of } \\
\text { acknowledgement, relationship, participation and communication. }\end{array}$ \\
\hline & $\begin{array}{l}\text { Authors reviewed: Bohlander and Snell (2009); Dessler (2002); Dietz, Wilkinson and Redman } \\
\text { (2010); Mathis and Jackson (2003); Muckinsky (2004); Sisson (1994); Ulrich et al. (1991); } \\
\text { Siqueira (2008). }\end{array}$ \\
\hline \multirow{2}{*}{$\begin{array}{l}\text { Training, } \\
\text { Development } \\
\text { \& Education } \\
\text { (TD\&E) }\end{array}$} & $\begin{array}{l}\text { Organizationally articulated proposal, with theoretical and practical constructions, to provide for } \\
\text { employees' systematic competence acquisition and to stimulate continuous learning and } \\
\text { knowledge production. }\end{array}$ \\
\hline & $\begin{array}{l}\text { Authors reviewed: Bohlander and Snell (2009); Borges-Andrade, Abbad and Mourão (2006); } \\
\text { Dessler (2002); Dutra (2001); Goldstein (1996); Sisson (1994); Winterton (2007). }\end{array}$ \\
\hline \multirow{2}{*}{$\begin{array}{l}\text { Work } \\
\text { Conditions } \\
\text { (WC) }\end{array}$} & $\begin{array}{l}\text { Organizationally articulated proposal, with theoretical and practical constructions, to provide } \\
\text { employees with good work conditions in terms of benefits, health, safety and technology. }\end{array}$ \\
\hline & $\begin{array}{l}\text { Authors reviewed: Bohlander and Snell (2009); Dessler (2002); Loudoun and Johnstone (2010); } \\
\text { Mathis and Jackson (2003); Osborn, Hunt and Schermerhorn (1998); Sisson (1994); Ulrich } \\
\text { (2001). }\end{array}$ \\
\hline \multirow{2}{*}{$\begin{array}{l}\text { Competency- } \\
\text { Based } \\
\text { Performance } \\
\text { Appraisal } \\
\text { (CBPA) }\end{array}$} & $\begin{array}{l}\text { Organizationally articulated proposal, with theoretical and practical constructions, to evaluate } \\
\text { employee's performance and competence, supporting decisions about promotions, career } \\
\text { planning and development. }\end{array}$ \\
\hline & $\begin{array}{l}\text { Authors reviewed: Bohlander and Snell (2009); Dessler (2002); Devanna, Fombrun and Tichy } \\
\text { (1984); Dutra (2001); Latham, Sulsky and Macdonald (2007); Mathis and Jackson (2003). }\end{array}$ \\
\hline \multirow{2}{*}{$\begin{array}{l}\text { Compensation } \\
\text { and Rewards } \\
\text { (CR) }\end{array}$} & $\begin{array}{l}\text { Organizationally articulated proposal, with theoretical and practical constructions, to reward } \\
\text { employees' performance and competence via remuneration and incentives. }\end{array}$ \\
\hline & $\begin{array}{l}\text { Authors reviewed: Bohlander and Snell (2009); Dessler (2002); Devanna et al. (1984); Dutra } \\
\text { (2001); Gerhart (2010); Hipólito (2001); Sisson (1994). }\end{array}$ \\
\hline
\end{tabular}

\section{Methods}

\section{Scale development}

As set by Pasquali (2008), and Kerlinger and Lee (2008), the development of a scale includes qualitative analysis. First of all, interviews are required for the definition of critical incidents that will subsidize the elaboration of the scale items. In a second step, theoretical analysis of the items should be performed, comprising the semantic analysis and analysis of judges. All participants were chosen by non-probabilistic convenience sampling.

Regarding the interviews, Bardin (2011) states that the group of participants should be diverse and representative. For this reason, respondents who answered the interviews work in organizations from various industries, such as banking, entertainment, consulting, education, telecommunications, engineering, healthcare, retail, food, beverages, beauty and fitness services. According to Bardin (2011), repetition in the response patterns indicates sufficiency of sample. Thus, in this step, the initial sample consisted of 30 participants.

Participants were interviewed and answered basically two questions: In your opinion, what is considered relevant in terms of HRM policies development for you to feel valued by the organization you work for? Which HRM practices would help promote your well-being at work as well as your 
commitment to achieve organizational goals? For analysis of the responses, we performed a categorical thematic content analysis as proposed by Bardin (2011).

As to the theoretical analysis of the items, they were first submitted to semantic analysis so that their understandability by the population members could be verified and doubts could be resolved. The analysis focused on a sample of 27 people, different from the 30 person initial sample, who work for organizations from different activities and industries, such as retail, education, public service, and banking. This sample was selected from the lowest (operational function) to the highest stratum of the target population (management function) to ensure the broadest possible understanding of the items. Then, the subjects were divided into small groups ( 5 or 6 ) and asked to explain the items in their own words to the other groups. If such explanation did not leave any doubt, the item was correctly understood. Otherwise, it would probably be a problematic item and likely excluded from the scale.

Next, after the semantic analysis, a judges' analysis was performed in late August of 2010, in order to check item consistency. Twelve (12) experts HRM (professors, HRM researchers and HRM managers) judged if the items were or were not referring to the factor (one of the 6 HRM policies) in question.

\section{Scale validation}

After the qualitative steps for the scale development, the questionnaire was ready for application. The 50 items were randomized in order to avoid bias (Kerlinger \& Lee, 2008). A specialized website, namely Google Docs, was used in order to make it available online. The link was spread across the researchers' contact lists. Hard copies were also given to colleagues, students and acquaintances. People current employed, 18 year-old or older and having completed at least a highschool education level were eligible to answer the questionnaire. The data collection returned 851 questionnaires. Using the criteria for sample sizes proposed by leading authors in Statistics (e.g., Byrne, 2009; Field, 2009; Hair, Black, Babi, Anderson, \& Tatham, 2009; Kline, 2011; Pasquali, 2008; Tabachnick \& Fidell, 2007), that is, between 5 or 10 subjects per item for EFA, or a minimum of 300 individuals, and a minimum of 400 subjects for CFA in case of complex models as ours, we determined we would need about 600 individuals. Thus, 851 subjects should be considered sufficient for the purposes of the present study, keeping in mind that data screening normally reduces sample size.

Data were examined and the assumptions for multivariate analysis were checked, following the procedures recommended by Myers (1990), Menard (2002), Tabachnick and Fidell (2007) and Hair, Black, Babi, Anderson, and Tatham (2009). Data was found to be very precise, with no registration errors or discrepancies in average and standard deviation measures. Also, there wasn't any case of multicollinearity or singularity as tolerance values were above 0.2 (Menard, 2002) and variance inflation factor (VIF) values were less than 5.0 (Myers, 1990). Analyses of outliers, normality and linearity were conducted as well, and 219 individuals from the original sample (851) were deleted by using the Mahalanobis distance criterion (D2 $=66.76$; $\mathrm{p}<0.001$ ). The percentage of missing data was lower than 5\%, which were excluded by the Listwise Deletion method (Hair et al., 2009; Tabachnick \& Fidell, 2007). The final sample was thus 632 participants, still enough to run the intended analysis. As previously mentioned, the sample diversity indicates sampling variability and representativeness.

For the exploratory factor analysis, an initial sample composed of 304 individuals was randomly selected from the final sample (632). The criterion recommended by Hair et al. (2009), says that for an adequate sample size, it is necessary to have between 5 and 10 individuals for each instrument item. To Tabachnick and Fidell (2007), factor analysis validity is compromised with less than 300 individuals. Similarly, Comrey and Lee recommend 300 as a good sample size. HRMPPS had 50 items in its application version, which would require a minimum sample size of 250 people, according to Hair et al. (2009) criterion. Three hundred and four (304) people composed a sample that attended to both criteria, allowing the exploratory and confirmatory validations to have different samples. 
As to the psychometric validation, we first performed an Exploratory Factor Analysis (EFA). The correlation matrix, the matrix determinant and the results of the Kaiser-Meyer-Olkin (KMO) sampling adequacy test were analyzed regarding factorability. For factor extraction, Principal Components Analysis (PCA) was used. Once the matrix was considered factorable, the eigenvalues, percentage of explained variance of each factor, scree plot graphic and parallel analysis were then examined in order to determine the quantity of factors to be extracted.

After defining the quantity of factors, we ran a Principal Axis Factoring (PAF) analysis using Promax rotation - since correlation among factors is expected in behavioral phenomena. Conbrach's alpha was used to check the consistency, precision or reliability of each factor. The statistic software used in these analyses was the Statistical Package for the Social Sciences (SPSS), version 18.0.

Next, a new validation of the structure obtained by the exploratory study was made with an independent sample, denominated the second sample, which was composed of an independent sample of the remaining 328 individuals. As this structure remained stable, the procedure continued using the total sample for the model's confirmatory factor validation. According to Kline (2011), complex models require larger samples. Hair et al. (2009), state that complex models, with more than 5 factors, require minimum sample sizes of 400 to 500 . To determine which factors' structure adjusts better to HRMPPS, its fit was evaluated by using AMOS 18 through the following indexes: NC (normatized chi-square or chi-square value divided by the model's degrees of freedom $=$ CMIN/DF), CFI (Comparative Fit Index) and RMSEA (Root Mean Square Error of Approximation), as recommended by Kline (2011). The internal consistency or reliability was measured through composite reliability (also known as Dillon-Goldstein's rho or Jöreskog's) as proposed by Chin (1998). Dillon-Goldstein's rho is a better reliability measure than Cronbach's alpha in Structural Equation Modeling, since it is based on the loadings rather than the correlations observed between the observed variables.

\section{Results}

\section{Scale development}

For the identification of categories and its indicators, we analyzed the categorical thematic content as recommended by Bardin (2011). The categories that emerged from content analysis were consistent with the six main policies cited in the literature, namely recruitment and selection, involvement, training, development and education, working conditions, competency-based performance appraisal, and compensation and rewards. These categories were the basis for confrontation with the literature and for the construction of the scale items. Thirty (30) items were generated from the interviews.

Thereafter, based on the literature review, another 18 items regarding the recruitment and selection and competency-based performance appraisal policies were formulated. In addition, 40 items concerning all policies were developed based on the most recently visited scientific literature. In total, the first version of the HRMPPS had 88 items.

At the end of the semantic analysis, 20 items were considered unclear, doubtful and repeated by the analysts. These items were crossed off and HRMPPS retained 68 items. Finally, after the judges' analysis, 18 items did not reach an application concordance to the factors for $80 \%$ of the judges or did not fit into only one factor and were therefore deleted from the instrument.

At the end, HRMPPS had 50 items in its application version, with a 5-point Likert scale, varying from I totally disagree to I totally agree. These were the items used for the quantitative analysis described in the following sections. 


\section{Scale validation}

\section{Exploratory factor analysis}

The analyses' results confirmed the matrix high factorability. KMO was 0.917 , classified by Kaiser (1974) as marvelous. The determinant of the correlation matrix was extremely close to zero, indicating that the number of factors is lower than the number of items.

Through Principal Components Analysis, it was possible to decide how many factors would be extracted. All the criteria adopted (eigenvalues higher than 1.0, explained variance percentage of each factor above 3\%, scree plot graphic visual analysis and parallel analysis) pointed to the existence of 6 factors. HRMPPS, after 8 iterations, resulted in a multifactorial instrument. Since the minimum acceptable load was defined as .32 (Pasquali, 2008), 10 items from the application version were not acceptable and the final version of HRMPPS comprised 40 items, distributed across 6 factors (subscales), representing HRM policies. The policies are compatible with the theoretical review, explaining $58 \%$ of the construct's total variance and meeting Hair et al. (2009) criterion that says a scale needs to have enough factors in order to explain about $60 \%$ of the construct variance.

The validity or quality of the items that composed each factor was also analyzed, based on Pasquali's (2008) statement that a valid item is the one that well represents the factor; that is, an item with a good factor loading. Comrey and Lee (1992) classified items with loadings higher or equal .71 as excellent; higher or equal .63 as very good; higher or equal .55 as good; higher or equal .45 as reasonable; and higher or equal .32 as poor. Thus, as to the items' quality, $70 \%$ of them were classified as excellent, very good and good.

Concerning the reliability, internal consistency or precision of the factors, Pasquali (2008) states that values above 0.70 indicate that the scale is reliable, while values above 0.80 indicate good reliability (Field, 2009). Nunnally and Bernstein (1994, pp. 264-265) say that "in the early stages of predictive or construct validation research," it may be "satisfactory" to "have only modest reliability, e.g., .70". For other scenarios, Nunnally and Bernstein (1994) go on to state that .80 or even .90 may be required. Peterson's (1994) meta-analytical study on alpha showed that reliable alphas have a .77 mean and .79 median.

All the 6 factors showed high reliability, with alpha coefficients higher than .80, following the threshold recommended by authors such as Nunnally and Bernstein (1994), and Peterson (1994). Tables 2, 3, 4, 5, 6 and 7 summarize the main information of each factor.

Table 2

\section{Description of the Items in Factor 1 (Recruitment and Selection)}

\begin{tabular}{clc}
\hline Item & Description & Loading \\
\hline I2 & $\begin{array}{l}\text { The organization I work for widely disseminates information about both external and internal } \\
\text { recruitment processes. }\end{array}$ & .75 \\
I8 & $\begin{array}{l}\text { The organization I work for discloses information to applicants regarding the steps and criteria } \\
\text { of the selection process. }\end{array}$ & .74 \\
I9 & $\begin{array}{l}\text { The organization I work for communicates performance results to candidates at the end of the } \\
\text { selection process. }\end{array}$ & .70 \\
I5 & Selection tests of the organization where I work are conducted by trained and impartial people. & .63 \\
I4 & The organization I work for has competitive selection processes that attract competent people. & .60 \\
I6 & The organization I work for uses various selection instruments (e.g. interviews, tests, etc.). & .50 \\
\hline
\end{tabular}

Note. This factor had a total of six items and reliability of .84 (Cronbach's $\alpha$ in EFA) and of .82 (Jöreskog's @ in CFA). 
Table 3

\section{Description of the Items in Factor 2 (Involvement)}

\begin{tabular}{llc}
\hline Item & Description & Loading \\
\hline I12 & The organization I work for treats me with respect and attention. & .91 \\
I11 & The organization I work for is concerned with my well-being. & .76 \\
I19 & $\begin{array}{l}\text { In the organization where I work, there is an environment of understanding and confidence } \\
\text { between managers and employees. }\end{array}$ & .73 \\
I17 & $\begin{array}{l}\text { The organization I work for recognizes the work I do and the results I achieve (e.g., in oral } \\
\text { compliments, in articles in corporate bulletins, etc.). }\end{array}$ \\
I21 & The organization I work for favors autonomy in doing tasks and making decisions. \\
I13 & The organization I work for seeks to meet my needs and professional expectations. \\
I18 & $\begin{array}{l}\text { In the organization where I work, employees and their managers enjoy constant exchange of } \\
\text { information in order to perform their duties properly. }\end{array}$ & .63 \\
I15 & $\begin{array}{l}\text { The organization I work for encourages my participation in decision- making and problem- } \\
\text { solving. }\end{array}$ & .63 \\
I20 & $\begin{array}{l}\text { In the organization where I work, there is an environment of trust and cooperation among } \\
\text { colleagues. }\end{array}$ & .62 \\
I16 & $\begin{array}{l}\text { The organization I work for encourages interaction among its employees (e.g., social } \\
\text { gatherings, social events, sports events, etc.). }\end{array}$ \\
I10 & The organization I work for follows up on the adaptation of employees to their functions. \\
I22 & $\begin{array}{l}\text { In the organization where I work, there is a consistency between discourse and management } \\
\text { practice. }\end{array}$ & .54 \\
\hline
\end{tabular}

Note. This factor had a total of twelve items and reliability of .93 (Cronbach's $\alpha$ in EFA) and of .92 (Jöreskog's @ in CFA).

Table 4

\section{Description of the Items in Factor 3 (Training, Development \& Education)}

\begin{tabular}{rlc}
\hline Item & Description & Loading \\
\hline I25 & I can use knowledge and behaviors learned in training at work. & .58 \\
I23 & $\begin{array}{l}\text { The organization I work for helps me develop the skills I need for the successful } \\
\text { accomplishment of my duties (e.g., training, conferences, etc.). }\end{array}$ \\
I24 & $\begin{array}{l}\text { The organization I work for invests in my development and education promoting my personal } \\
\text { and professional growth in a broad manner }(e . g .,\end{array}$ & .56 \\
& $\begin{array}{l}\text { degrees, postgraduate programs, language courses, etc.). } \\
\text { I30 }\end{array}$ & In the organization where I work, training is evaluated by participants. \\
I28 & The organization I work for stimulates learning and application of knowledge. & .54 \\
I29 & In the organization where I work, training needs are identified periodically. & .49 \\
\hline
\end{tabular}

Note. This factor had a total of six items and reliability of .88 (Cronbach's $\alpha$ in EFA) and of .88 (Jöreskog's @ in CFA). 
Table 5

\section{Description of the Items in Factor 4 (Work Conditions)}

\begin{tabular}{rlr}
\hline Item & Description & Loading \\
\hline I34 & $\begin{array}{l}\text { The organization I work for provides basic benefits }(e . g ., \text { health care, transportation } \\
\text { assistance, food aid, etc.). }\end{array}$ & .86 \\
I36 & $\begin{array}{l}\text { The organization I work for has programs or processes that help employees cope with } \\
\text { incidents and prevent workplace accidents. }\end{array}$ & .64 \\
I37 & $\begin{array}{l}\text { The organization I work for is concerned with the safety of their employees by having access } \\
\text { control of people who enter the company building/facilities. }\end{array}$ \\
I35 & $\begin{array}{l}\text { The organization I work for provides additional benefits }(e . g ., \text { membership in gyms, country } \\
\text { clubs, and other establishments, etc.). }\end{array}$ \\
I38 & $\begin{array}{l}\text { The facilities and physical condition (lighting, ventilation, noise and temperature) of the } \\
\text { organization I work for are ergonomic, comfortable, and appropriate. }\end{array}$ \\
I33 & The organization I work for is concerned with my health and quality of life. & .57 \\
\hline
\end{tabular}

Note. This factor had a total of six items and reliability of .84 (Cronbach's $\alpha$ in EFA) and of . 80 (Jöreskog's @ in CFA).

Table 6

\section{Description of the Items in Factor 5 (Competency-Based Performance Appraisal)}

\begin{tabular}{clc}
\hline Item & Description & Loading \\
\hline I43 & $\begin{array}{l}\text { The organization I work for discusses competency-based performance appraisal criteria and } \\
\text { results with its employees. }\end{array}$ & .92 \\
I42 & $\begin{array}{l}\text { In the organization where I work, competency-based performance appraisal provides the basis } \\
\text { for an employee development plan. }\end{array}$ & .86 \\
I41 & $\begin{array}{l}\text { In the organization where I work, competency-based performance appraisal is the basis for } \\
\text { decisions about promotions and salary increases. }\end{array}$ \\
I44 & $\begin{array}{l}\text { The organization I work for disseminates competency-based performance appraisal criteria } \\
\text { and results to its employees. }\end{array}$ & .71 \\
I40 & The organization I work for periodically conducts competency-based performance appraisals. & .55 \\
\hline
\end{tabular}

Note. This factor had a total of five items and reliability of .86 (Cronbach's $\alpha$ in EFA) and of .91 (Jöreskog's Q in CFA).

Table 7

Description of the Items in Factor 6 (Compensation and Rewards)

\begin{tabular}{clc}
\hline Item & Description & Loading \\
\hline I47 & $\begin{array}{l}\text { In the organization where I work, I get incentives such as promotions, commissioned } \\
\text { functions, awards, bonuses, etc. }\end{array}$ & .66 \\
I50 & In the organization where I work, my salary is influenced by my results. \\
I46 & $\begin{array}{l}\text { The organization I work for offers me a salary that is compatible with my skills, training, and } \\
\text { education. }\end{array}$ & .56 \\
I45 & $\begin{array}{l}\text { The organization I work for remunerates me according to the remuneration offered at either } \\
\text { the public or private marketplace levels. }\end{array}$ \\
I49 & $\begin{array}{l}\text { The organization I work for considers the expectations and suggestions of its employees when } \\
\text { designing a system of employee rewards. }\end{array}$ & .45 \\
\hline
\end{tabular}

Note. This factor had a total of five items and reliability of .81 (Cronbach's $\alpha$ in EFA) and of .86 (Jöreskog's Q in CFA). 


\section{Validation of the structure in a different sample}

Table 8 shows that the six-factor structure obtained for HRMPS with the sample of 304 employees revealed itself to be stable when applied in an independent sample of 328 employees. Considering the main psychometric indexes of an instrument, namely the explained variance's total, the quantity of items and the precision of the factors measured by Cronbach's alpha, it is possible to observe that the results are very similar in both validations, regarding reliability and percentage of explained variance, but the validation of the sample of 328 ended up with fewer items (37). The 6 factors can be named and interpreted in the same way as in the initial structure, that is, factor 1: recruitment and selection; factor 2: involvement; factor 3: training, development and education; factor 4: work conditions; factor 5: competency-based performance appraisal; and factor 6: compensation and rewards.

Table 8

\section{Comparison among the Obtained Factor structures}

\begin{tabular}{lcc}
\hline Items of comparison & Sample of 304 & Sample of 328 \\
\hline Percentage of explained variance & $58 \%$ & $60 \%$ \\
Number of items / Cronbach's alpha of factor 1 & $6 / 0.84$ & $7 / 0.84$ \\
Number of items / Cronbach's alpha of factor 2 & $12 / 0.93$ & 12 / 0.92 \\
Number of items / Cronbach's alpha of factor 3 & $6 / 0.88$ & $6 / 0.90$ \\
Number of items / Cronbach's alpha of factor 4 & $6 / 0.84$ & $5 / 0.80$ \\
Number of items / Cronbach's alpha of factor 5 & $5 / 0.86$ & $4 / 0.88$ \\
Number of items / Cronbach's alpha of factor 6 & $5 / 0.81$ & $3 / 0.82$ \\
\hline
\end{tabular}

Thereby, with the initial factor structure validated, testing the generalization of the scale, we continued with confirmatory analysis.

\section{Confirmatory factor analysis}

To perform the confirmatory factor validation of the new HRMPPS, using structural equations, we used the sample of 632 employees. We ran a CFA from the factor structure obtained in the exploratory analysis and chose the maximum likelihood method to estimate all models.

As to dimensionality assessment, Byrne (2009) states that in a confirmatory factor analysis, a one-factor model should be tested before a multiple-factor model. So, in this study, two measurement models were tested and compared: Model 1, a one-factor model (see Figure 1), with HRM policies and practices (HRMPP) as the latent variable and the 40 items representing HR practices as observed variables; and Model 2, a six-factor model structure obtained in the EFA (see Figure 2).

According to Kline (2011), values which indicate satisfactory adjustment for a model are: for $\mathrm{NC}$ (CMIN/DF), values 2.0 or 3.0 or, at most, up to 5.0; for CFI, values higher than .90 and for RMSEA, values lower than .06 or up to .08. Model 1 showed 121 parameters, with $\chi 2_{(767)}=5652.11$, $\mathrm{p}<0.001 ; \mathrm{df}=767 ; \mathrm{p}<0.001$ or $\mathrm{NC}=7.64 ; \mathrm{CFI}=.66$; RMSEA $=.103$ (confidence interval from .100 to .105). Therefore, the one-factor model provided for a poor fit. 


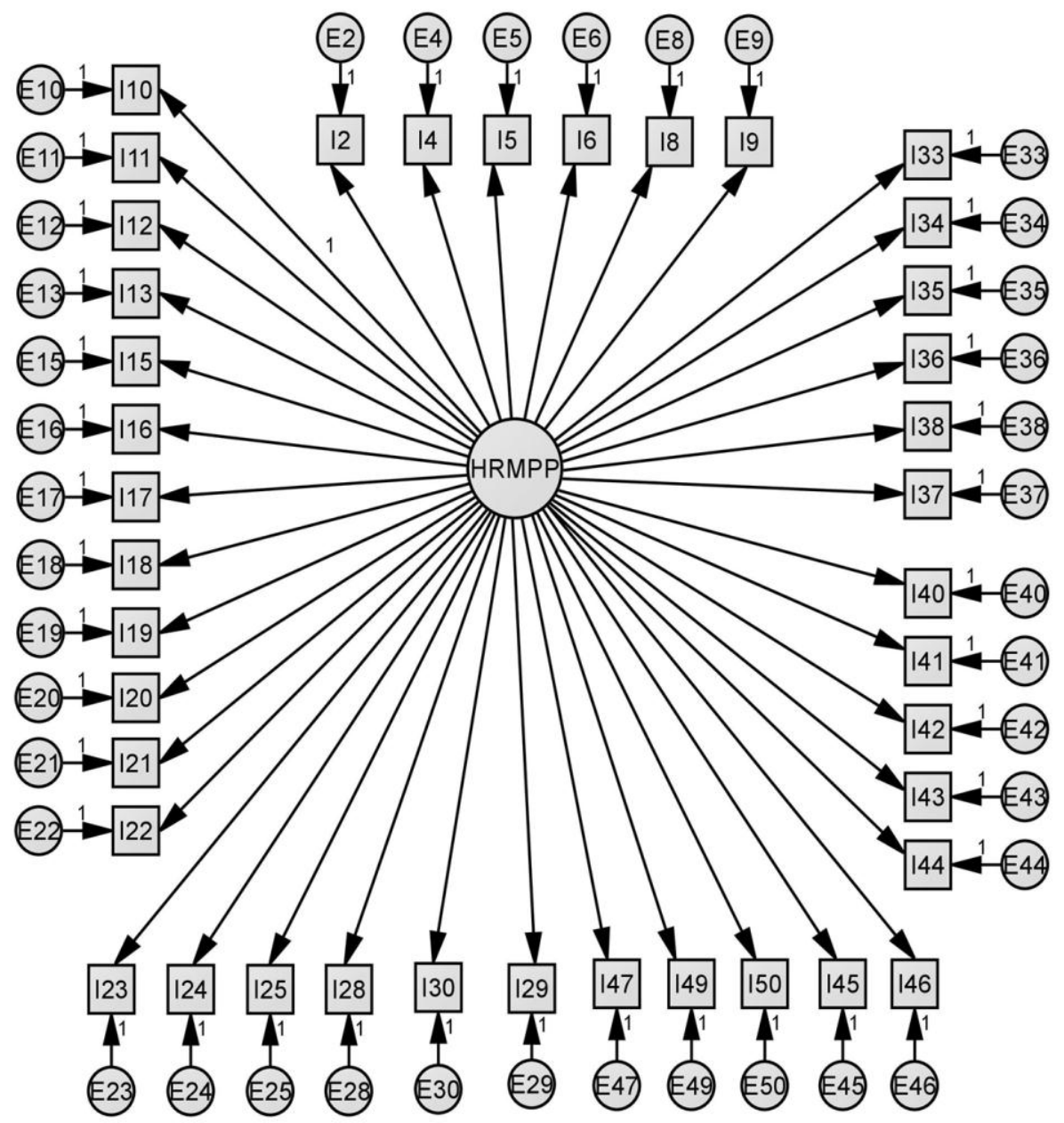

121 parameters; $X 2(767)=5652.11, p<0.001 ; d f=767 ; p<0.001$ or $\mathrm{NC}=7.64 ; \mathrm{CFI}=.66 ; \mathrm{RMSEA}=.103$ (confidence interval from .100 to .105 ).

Figure 1. Model 1.

On the other hand, the hypothesized six-factor model (Model 2) was tested and confirmed, providing better indices and a reasonable fit (Figure 2). The final model held 141 parameters, with $\chi 2_{(752)}=2376.2,29, \mathrm{p}<0.001 ; \mathrm{df}=752 ; \mathrm{p}<0.001$ or $\mathrm{NC}=3.15 ; \mathrm{CFI}=.89 ; \mathrm{RMSEA}=.07$ (confidence interval from .069 to .075 ). The factor loadings of the items in the confirmatory validation were between .55 and .88, showing good- quality items, according to Comrey and Lee (1992).

It is important to emphasize that in the confirmatory analysis the same multifactorial structure of 40 items distributed across 6 factors was kept, in agreement with the reviewed literature and exploratory validation, such that the interpretation of the factors is the same as displayed in Tables 2 to 7. The results confirmed the HRMPPS' validation by showing the conceptual suitability of the structure obtained in the exploratory analysis and reasonable fit. The six-factor model is represented in Figure 2. 


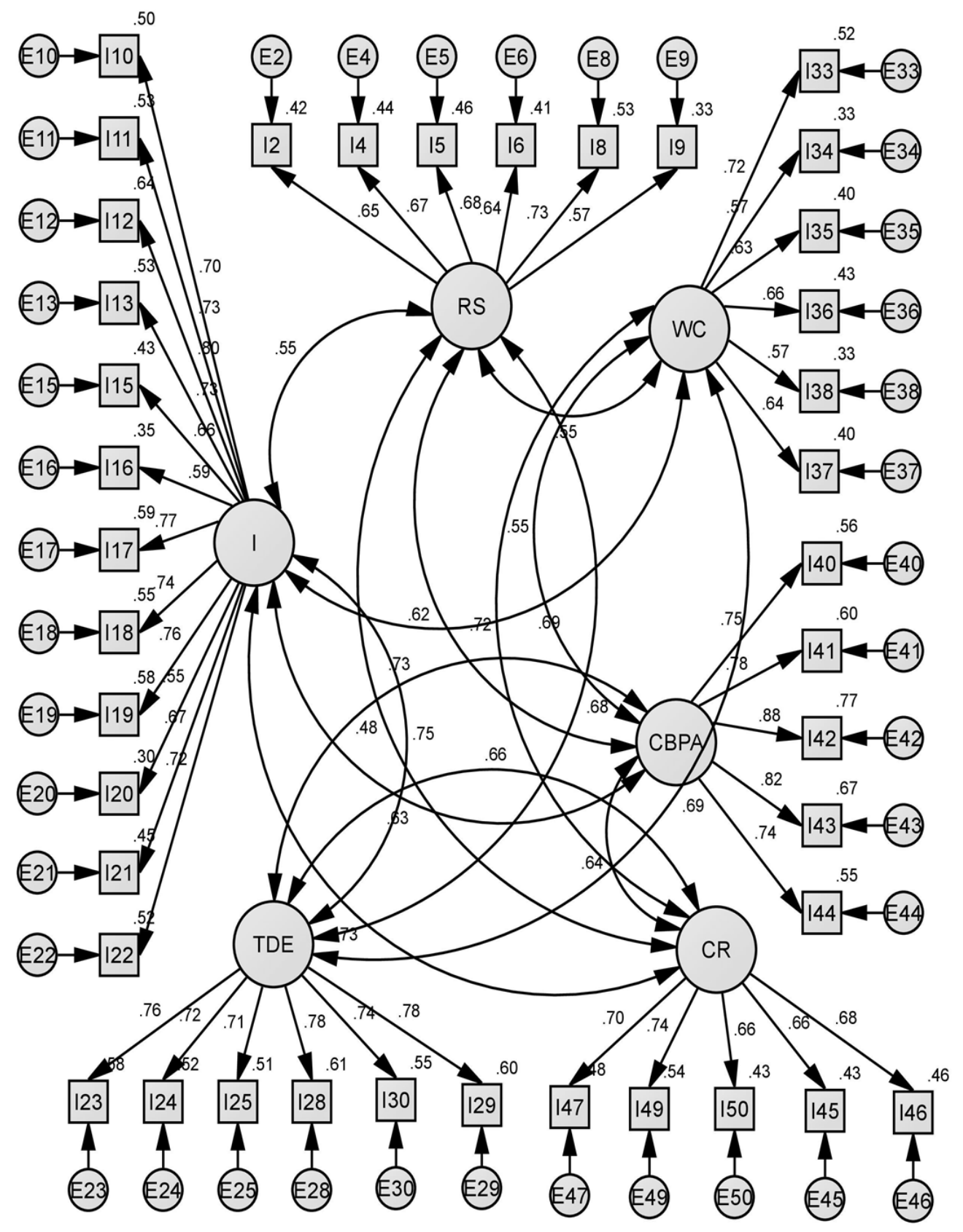

141 parameters; $\mathrm{x} 2(752)=2376.2,29, \mathrm{p}<0.001 ; \mathrm{df}=752 ; \mathrm{p}<0.001$ or $\mathrm{NC}=3.15 ; \mathrm{CFI}=.89$; RMSEA $=.07$ (confidence interval from .069 to .075 )

Figure 2. Model 2.

Taken together, model 2 (six-factor model) was found to outperform model 1 (one-factor model) for all measures. In addition, chi-square difference was significant $\left(\Delta \chi_{(15)}^{2}=2556,82\right.$, $\mathrm{p}<0.001)$, indicating that Model 2 is indeed better than Model 1. These results suggest that HRM policies and practices are a multi-dimensional construct that consists of six dimensions and 40 items.

To assess the reliabilities of the six subscales of HRM Policies and Practices, Jöreskog's rho was computed for each factor. Chin (1998) recommends that acceptable scores for the Jöreskog's rho should be higher than 0.70 . The results were very satisfactory, ranging from .80 through .92 for all the six factors. Specifically: recruitment and selection policy $(\varrho=.82)$, involvement policy $(\varrho=.92)$, training, development and education policy $(\varrho=.88)$, work conditions policy $\left(\varrho^{=}=80\right)$, competencybased performance appraisal policy $(\varrho=.91)$ and compensation and rewards policy $(\varrho=.86)$. 
Construct validity is the degree to which a set of measured items actually reflects the theoretical latent construct that those items are supposed to measure (Hair et al., 2009). In this study, the construct validity of the HRMPPS was examined by assessing convergent and discriminant validity.

Convergent validity refers to the degree of agreement between two or more measures of the same construct. According to Hair et al. (2009), there are several indicators of convergent validity, for example, examining factor loadings and the factor reliability. As we have seen, the reliability of all six factors were above $\varrho=.70$, indicating appropriate convergence (Hair et al., 2009). In addition, all items of the HRM Policies and Practices measure loaded significantly positive onto their specified factor (see Figure 2). All 40 items presented loadings over .5 (Hair et al., 2009) for the factors to which they were assigned; this is indeed a test of convergent validity of the scale. We may thus state that the scales for these six HRMPP dimensions possessed convergent validity.

Discriminant validity indicates the degree to which measures of conceptually distinct constructs differ. In this study it was assessed as follows: AFC was performed for a selected pair of constructs/factors, allowing correlation between the two constructs. The chi-square value of this model was noted. Then, the AFC was performed again for the same pair of constructs, setting the correlation between the two constructs equal to 1 . The chi-square value of the second model was then noted. We then calculated the difference between the values of the chi-squares and also the difference of degrees of freedom for both models. Finally, we analyzed the differences between the chi-square values and between the degrees of freedom in a chi-square table: statistically significant values indicate the existence of discriminant validity.

The test was conducted for each pair of constructs, resulting in 15 tests. The results on Table 9 showed that all chi-square differences are significant. There is evidence, then, that the constructs are different and have discriminant validity.

\section{Table 9}

Discriminant Validity

\begin{tabular}{lccccc}
\hline Constructs & $\begin{array}{c}\text { Recruitment } \\
\text { and Selection }\end{array}$ & Involvement & TD\&E & $\begin{array}{c}\text { Work } \\
\text { Conditions }\end{array}$ & CBPA \\
\hline Involvement & $\Delta \chi_{(1)}^{2}=79.5$ & & & \\
& $\mathrm{p}<0.001$ & & & & \\
Training, & $\Delta \chi_{(1)}^{2}=32.34$ & $\Delta \chi_{(1)}^{2}=81.9$ & & & \\
Development and & $\mathrm{p}<0.001$ & $\mathrm{p}<0.001$ & & & \\
Education & & & & & \\
Work Conditions & $\Delta \chi_{(1)}^{2}=68.7$ & $\Delta \chi_{(1)}^{2}=47.5$ & $\Delta \chi_{(1)}^{2}=25.8$ & & \\
& $\mathrm{p}<0.001$ & $\mathrm{p}<0.001$ & $\mathrm{p}<0.001$ & & \\
Competency-Based & $\Delta \chi_{(1)}^{2}=36.6$ & $\Delta \chi_{(1)}^{2}=38.9$ & $\Delta \chi_{(1)}^{2}=8.9$ & $\Delta \chi_{(1)}^{2}=42.9$ & $\mathrm{p}<0.001$ \\
$\begin{array}{l}\text { Performance } \\
\text { Appraisal }\end{array}$ & $\mathrm{p}<0.001$ & $\mathrm{p}<0.001$ & $\mathrm{p}<0.005$ & & \\
Compensation and & $\Delta \chi_{(1)}^{2}=79.9$ & $\Delta \chi_{(1)}^{2}=40.6$ & $\Delta \chi_{(1)}^{2}=30.8$ & $\Delta \chi_{(1)}^{2}=31.2$ & $\Delta \chi_{(1)}^{2}=28.4$ \\
Rewards & $\mathrm{p}<0.001$ & $\mathrm{p}<0.001$ & $\mathrm{p}<0.001$ & $\mathrm{p}<0.001$ & $\mathrm{p}<0.001$ \\
\hline
\end{tabular}

In summary, we found evidence of both convergent and discriminant validity, and thus our findings lend support to the construct validity of the six-factor model of HRM policies and practices. 


\section{Discussion}

Even though the numbers resulting from the previous analysis were very satisfactory, it is also necessary to analyze HRMPPS's theoretical consistency with the revised literature, verifying if the scale's items are coherent with the theoretical concepts used to support it. Pasquali (2008) and Kerlinger and Lee (2008) have said that it is not appropriate to hold a factor that has only a mathematic meaning, for the factor must be relevant in the scientific theoretical context. HRMPPS's 40 items indeed have theoretical support, greatly corresponding to the literature review of each policy as discussed below.

About the recruitment and selection policy, Dessler (2002), and Mathis and Jackson (2003) have suggested the vast disclosure of external and internal recruitment processes, as well as of information concerning the selective process' stages, criteria, performance and results as important points. They are also present in the scale with a strong factor loading, indicating its representativeness in the construct. The importance of using several selection instruments, defended by authors like Bohlander and Snell (2009), Dessler (2002), and Mathis and Jackson (2003), is also an aspect of HRMPPS.

And, finally, there are items illustrating the ideas found in Lievens and Chapman (2010), that professionals responsible for a recruitment and selection process have to be capable and impartial since they perform a fundamental and determinant role in the process. According to these authors, companies with a good organizational image become more attractive and have the possibility of selecting the best-prepared professionals.

Dietz, Wilkinson and Redman (2010) discussed the involvement policy and its practices by legitimating the employees' participation in decision-making and problem-solving as well as greater integration among them. Bohlander and Snell (2009) highlighted the importance of employees' adaptation to their positions, the existence of an environment of understanding, cooperation and trust as a way of creating involvement, and the coherence between managerial speech and practice, practices present in HRMPPS. Muckinsky (2004) and Siqueira (2008) emphasized the respectful and attentive treatment given to employees, as well as caring for their well-being as fundamental aspects to involve them. It is important to note that the illustrative items of this point are the ones with the highest factor loadings of the involvement policy, thus showing the convergent validity of the items with the concept they represent.

The other scale's items also have theoretical support. Bohlander and Snell (2009), Dessler (2002) and Mathis and Jackson (2003) suggested the autonomy in task performance and decisionmaking, as well as the empowerment, as involvement characteristic actions. Additionally, Sisson (1994) alerted to the importance of continuous recognition and feedback and the constant exchange of information between employees and managers as important practices of involvement. Finally, Ulrich et al. (1991) emphasized the necessity of establishing partner relationships with employees by identifying their needs, values and worries.

The scale's items referring to the TD\&E practices also have theoretical support. BorgesAndrade, Abbad and Mourão (2006) and Goldstein (1996) explained the differences between the concepts of training, development and education, emphasizing the importance of evaluating training impact at work. Winterton (2007) highlighted that decisions regarding the necessity of training in an organization must be identified periodically, being influenced by national and sectorial culture.

Sisson (1994) and Dessler (2002), in turn, discussed the need that organizations have to especially invest in development and education, given their strategic-long term character. Thus, modern methods of training, managerial development and career management assume special connotations. In this context, Dutra (2001) affirmed that TD\&E policy plays an important role in the development of necessary competences to perform functions, illustrating distance education and the corporate universities' model as innovative in this process. Finally, Bohlander and Snell (2009) 
indicated that the stimulus for learning and knowledge application must be at the heart of TD\&E policy.

Regarding the items referring to work conditions policy, Loudoun and Johnstone (2010) dealt with occupational health and work safety, referring to a suitable environment and auspicious conditions for maintaining the physical, psychic and mental welfare of the individuals, synthesizing items with high factor loading in the HRMPPS' validation. Sisson (1994), Osborn, Hunt and Schermerhorn (1998), Dessler (2002) and Mathis and Jackson (2003) confirmed the importance of offering basic (the most representative item of the work conditions policy in the HRMPPS' validation) and complementary benefits to the employees. Mathis and Jackson (2003) and Ulrich (2001) also pointed the importance of an ergonomic approaching on the project of functions, environment and positions.

Items concerning the competency-based performance appraisal policy also have found support in the reviewed literature. According to Latham, Sulsky and Macdonald (2007), management feedback concerning employee performance is a crucial point, referring to the goals and results reached. From this, the authors highlight that it's important to remember that the criteria's definition for performance evaluation can be elaborated together with the employees, stimulating their involvement and participation in the process. Such an item presented the highest factor loading in this policy.

Aligned to these ideas, Dessler (2002), Mathis and Jackson (2003) and Bohlander and Snell (2009), defended performance evaluation as the principal method for elaborating an employee development plan and for decision-making regarding promotion and salary increases. Dutra (2001) emphasized the need of evaluating, besides performance, employee competences since they might be indicatives of the potential for future contribution to the organization. Finally, Devanna, Fombrun and Tichy (1984) certified the need for periodical evaluations and, in this sense, Bohlander and Snell (2009) recommended a maximum period of 1 year between evaluations, with 6 months as the ideal period.

Finally, regarding the items representing practices validated in the compensation and rewards policy, Gerhart (2010) argued that it must be result of careful choices by managers, as it is one of an organization's most impactful strategic policies. According to the author, the main questions for decision making are "how to pay" (offered rewards), considered to be the most strategic in the decision-making process, and "how much to pay". Referring to how much to pay, remuneration must be compatible with both the employee's education and marketplace levels, as Sisson (1994) and Bohlander and Snell (2009) defend.

Also, Devanna et al. (1984) understood that a compensation policy must also include rewards and incentives like prizes and bonuses, and a career plan for everyone, besides remuneration. The practice of incentives was present in the item with the highest factor loading in the compensation and rewards policy's validation. On the same line, Hipólito (2001), Dutra (2001) and Dessler (2002) highlighted variable remuneration methods, such as prizes, gratification, profit participation and action options, competency-based promotion and broadbanding (fewer, but broader pay ranges indicating an easier way to professional promotion) as remuneration tendencies in the new millennium. Finally, the authors suggested considering employee expectations and suggestions on reward designs in order to make them as customized as possible, and further, that remuneration must depend on results so that the effort-reward relation is clear among employees, preventing revenge attitudes.

Table 10 summarizes the 40 items of the HRMPPS, the respective construct and their theoretical background. 
Table 10

\section{Items of the HRMPPS, Construct and its Theoretical Background}

Item

I2. The organization I work for widely disseminates information about both external and internal recruitment processes.

I8. The organization I work for discloses information to applicants regarding the steps and criteria of the selection process.

I9. The organization I work for communicates performance results to candidates at the end of the selection process.

I5. Selection tests of the organization where I work are conducted by trained and impartial people.

I4. The organization I work for has competitive selection processes that attract competent people.

I6.The organization I work for uses various selection instruments (e.g. interviews, tests, etc.).

I12. The organization I work for treats me with respect Involvement and attention.

I11. The organization I work for is concerned with my Involvement well-being.

I19. In the organization where I work, there is an environment of understanding and confidence between managers and employees.

I17. The organization I work for recognizes the work I Involvement do and the results I achieve (e.g., in oral compliments, in articles in corporate bulletins, etc.).

I21. The organization I work for favors autonomy in doing tasks and making decisions.

I13. The organization I work for seeks to meet my needs and professional expectations.

I18. In the organization where I work, employees and their managers enjoy constant exchange of information in order to perform their duties properly.

I15. The organization I work for encourages my participation in decision- making and problem- solving.

I20. In the organization where I work, there is an environment of trust and cooperation among colleagues.

I16. The organization I work for encourages interaction among its employees (e.g., social gatherings, social events, sports events, etc.).

I10. The organization I work for follows up on the adaptation of employees to their functions.
Construct

Theoretical Background

Recruitment and Selection Dessler (2002); Mathis and Jackson (2003)

Recruitment and Selection Dessler (2002); Mathis and Jackson (2003)

Recruitment and Selection Dessler (2002); Mathis and Jackson (2003)

Recruitment and Selection Lievens and Chapman (2010)

Recruitment and Selection Lievens and Chapman (2010)

Recruitment and Selection Dessler (2002); Mathis and Jackson (2003); Bohlander and Snell (2009)

Muckinsky (2004);

Siqueira (2008)

Muckinsky (2004);

Siqueira (2008)

Involvement

Bohlander and Snell (2009)

Sisson (1994)

Involvement

Bohlander and Snell (2009); Dessler (2002); Mathis and Jackson (2003)

Ulrich et al. (1991)

Sisson (1994)

Dietz et al. (2010)

Bohlander and Snell (2009)

Dietz et al. (2010)

Involvement

Bohlander and Snell (2009) 
Table 10 (continued)

Item
I22. In the organization where I work, there is a
consistency between discourse and management
practice.
I25. I can use knowledge and behaviors learned in
training at work.
I23. The organization I work for helps me develop the
skills I need for the successful accomplishment of my
duties (e.g., training, conferences, etc.).
I24. The organization I work for invests in my
development and education promoting my personal
and professional growth in a broad manner (e.g., full or
partial sponsorship of undergraduate degrees,
postgraduate programs, language courses, etc.).

I30. In the organization where I work, training is evaluated by participants.

I28. The organization I work for stimulates learning and application of knowledge.

I29. In the organization where I work, training needs are identified periodically.

I34. The organization I work for provides basic benefits (e.g., health care, transportation assistance, food aid, etc.).

I36. The organization I work for has programs or processes that help employees cope with incidents and prevent workplace accidents.

I37. The organization I work for is concerned with the safety of their employees by having access control of people who enter the company building/facilities.

I35. The organization I work for provides additional benefits (e.g., membership in gyms, country clubs, and other establishments, etc.).

I38. The facilities and physical condition (lighting, ventilation, noise and temperature) of the organization I work for are ergonomic, comfortable, and appropriate.

I33. The organization I work for is concerned with my health and quality of life.

I43. The organization I work for discusses competency-based performance appraisal criteria and results with its employees.

I42. In the organization where I work, competencybased performance appraisal provides the basis for an employee development plan.

I41. In the organization where I work, competencybased performance appraisal is the basis for decisions about promotions and salary increases.

\section{Construct}

Involvement

Training, Development \& Education

Training, Development \& Education

Training, Development \& Education

Training, Development \& Education

Training, Development \& Education

Training, Development \& Education

Work Conditions

Work Conditions

Work Conditions

Work Conditions

Work Conditions

Work Conditions

Competency-Based

Performance Appraisal

Competency-Based

Performance Appraisal

Competency-Based

Performance Appraisal
Sisson (1994); Dessler (2002)

Theoretical Background

Bohlander and Snell

(2009)

Borges-Andrade et al. (2006); Goldstein (1996)

Dutra (2001)

Goldstein (1996); BorgesAndrade et al. (2006)

Bohlander and Snell (2009)

Winterton (2007)

Sisson (1994); Osborn et al. (1998); Dessler (2002); Mathis and Jackson (2003)

Loudoun and Johnstone (2010)

Loudoun and Johnstone (2010)

Sisson (1994); Osborn et al. (1998); Dessler (2002); Mathis and Jackson (2003)

Ulrich (2001); Mathis and Jackson (2003)

Loudoun and Johnstone (2010)

Latham et al. (2007)

Dessler (2002); Mathis and Jackson (2003); Bohlander and Snell (2009)

Dessler (2002); Mathis and Jackson (2003); Bohlander and Snell (2009) 
Table 10 (continued)

\begin{tabular}{|c|c|c|}
\hline Item & Construct & Theoretical Background \\
\hline $\begin{array}{l}\text { I44. The organization I work for disseminates } \\
\text { competency-based performance appraisal criteria and } \\
\text { results to its employees. }\end{array}$ & $\begin{array}{l}\text { Competency-Based } \\
\text { Performance Appraisal }\end{array}$ & Latham et al. (2007) \\
\hline $\begin{array}{l}\text { I40. The organization I work for periodically conducts } \\
\text { competency-based performance appraisals. }\end{array}$ & $\begin{array}{l}\text { Competency-Based } \\
\text { Performance Appraisal }\end{array}$ & $\begin{array}{l}\text { Devanna et al. (1984); } \\
\text { Dutra (2001) }\end{array}$ \\
\hline $\begin{array}{l}\text { I47. In the organization where I work, I get incentives } \\
\text { such as promotions, commissioned functions, awards, } \\
\text { bonuses, etc. }\end{array}$ & $\begin{array}{l}\text { Compensation and } \\
\text { Rewards }\end{array}$ & Devanna et al. (1984) \\
\hline $\begin{array}{l}\text { I50. In the organization where I work, my salary is } \\
\text { influenced by my results. }\end{array}$ & $\begin{array}{l}\text { Compensation and } \\
\text { Rewards }\end{array}$ & $\begin{array}{l}\text { Hipólito (2001); Dutra } \\
\text { (2001) }\end{array}$ \\
\hline $\begin{array}{l}\text { I46. The organization I work for offers me a salary that } \\
\text { is compatible with my skills, training, and education. }\end{array}$ & $\begin{array}{l}\text { Compensation and } \\
\text { Rewards }\end{array}$ & $\begin{array}{l}\text { Sisson (1994); Bohlander } \\
\text { and Snell (2009); Gerhart } \\
(2010)\end{array}$ \\
\hline $\begin{array}{l}\text { I45. The organization I work for remunerates me } \\
\text { according to the remuneration offered at either the } \\
\text { public or private marketplace levels. }\end{array}$ & $\begin{array}{l}\text { Compensation and } \\
\text { Rewards }\end{array}$ & $\begin{array}{l}\text { Sisson (1994); Bohlander } \\
\text { and Snell (2009); Gerhart } \\
(2010)\end{array}$ \\
\hline $\begin{array}{l}\text { I49. The organization I work for considers the } \\
\text { expectations and suggestions of its employees when } \\
\text { designing a system of employee rewards. }\end{array}$ & $\begin{array}{l}\text { Compensation and } \\
\text { Rewards }\end{array}$ & Dessler (2002) \\
\hline
\end{tabular}

Thereafter, we might affirm that HRMPPS's 40 items indeed have theoretical support, greatly corresponding to the literature reviewed throughout this paper.

Concerning the confirmatory factor analysis, the six-factor structure obtained through the exploratory factor analysis was confirmed, showing a satisfactory fit with respect to NC and RMSEA indexes, in spite of presenting an unsatisfactory fit regarding the GFI fit. According to Hair et al. (2009), researchers should not rely on just one measure of fit, that's why the authors recommend researchers to use at least one absolute index (e.g., RMSEA) and one incremental index (e.g., CFI), in addition to the chi-square value and its degrees of freedom associated or NC.

Although the CFI did not reached the minimum value of 0.90 to be considered satisfactory, despite being very close (0.89), the RMSEA, in turn, represents how well a better model fits a population and a sample not used only for estimation, as it is a more suitable index for use when samples become larger (> 500), as Hair et al. (2009) state. Furthermore, the authors argue that with samples larger than 250 and complex models (more than 30 variables), as in this research, RMSEA values up to 0.07 indicate good quality fit and chi-squares values could be significant $(\mathrm{p}<.05)$. In other words, more complex models with larger samples require less strict criteria for evaluation.

Besides, the satisfactory value of NC may indicate that the variables comprising the HRM policies and practices factors were well specified, attesting to the reliability of the indicators used. Also, such indicators loaded significantly positive on their specified factor showing convergent validity. Therefore, we might consider the fit indexes reached by the confirmatory validation acceptable, bringing indications of validity, and thus further evaluations in other samples are encouraged.

Ultimately, HRMPPS sought to improve the fullness and reliability of the scales already found in the literature. The objective of this study was reached and a multifactorial instrument with 40 items, distributed across 6 factors, explaining around 58\% of the construct's total variance, was produced in agreement with the performed literature review, with high-reliability and construct validity. 


\section{Academic and Managerial Implications}

The present study makes both academic and practical contributions, and suggests some applications for the research.

First, we explore the strategic nature of HRM, provide a clear conceptualization of the construct, and then develop a conceptual model with the six policies most cited in the literature, namely, recruitment and selection; involvement; training, development and education; work conditions; competency-based performance appraisal; compensation and rewards. Though some of the ideas expressed in this conceptual model are familiar to HRM specialists, its value is in integrating these various notions to provide a more comprehensive and holistic picture of HRM policies and practices.

Second, we provide empirical evidence for the testable scales that are both reliable and valid. This gives a new theoretical insight into how HRM policies and practices can be managed to provide superior organizational outcomes. Third, the research contributed to scientific production in HRM, Organizational Psychology and Management and Organizations field since HRMPPS or its 6 subscales can be used separately in relational studies. Furthermore, HRMPPS, validated trough exploratory and confirmatory factor analysis, is a comprehensive and reliable measure considering the importance of developing profitable HRM policies in the organizations, as well as the gap in literature concerning measures of perceptions of HRM policies.

As to the managerial implications, HRMPPS covers most of the policies used in the organizations, constituting an important evaluation instrument for managers to improve their employee's well-being at work. There is a consensus in the literature that HRM policies and practices positively impact well-being at work. Nishii, Lepak and Schneider (2008) assert that HRM practices should be designed to enhance well-being at work. Similarly, Turner, Huemann and Keegan (2008) point out that HRM traditionally has two roles: (a) management support, providing the organization with competent people to perform the work processes; and (b) staff support, looking after their wellbeing. Additionally, the study performed by Baptiste (2008) showed that HRM practices significantly impact well-being at work.

In addition, there is theoretical and empirical evidence that HRM policies and practices indeed favorably affect organizational performance (e.g., Boselie et al., 2005; Ezzamel et al., 1996; Guest \& Conaway, 2011; Guest \& Hoque, 1994; Katou, 2012; Menezes et al., 2010; Subramony, 2009). Consequently, since the Human Resource Management Policies and Practices Scale includes the most widely studied HRM policies and practices, it might support managers decision-making and problemsolving regarding identification of HRM areas where specific improvements are needed in order to improve organizational performance.

\section{Limitations and Directions for Future Research}

This research has limitations and consequently recommendations for future studies. Our proposal represents an attempt to build and test a conceptual framework of HRM policies and practices. Then, a first limitation is that the present findings are therefore indicative rather than conclusive. It would be useful to further assess the generalizability of the HRMPPS to other business environments such as American, European and Asian countries. Moreover, with more replicative and creative research, a more comprehensive conceptual framework related to HRM policies and practices can be developed in the future.

Second, in spite of having a reasonable fit, the six-factor model didn't present a good incremental index (CFI), indicating the necessity of new tests and other specifications, to generally 
improve the model fit. The models using structural equations tend to present excellent fit indices in situations where the measures have a good delimitation and theoretical precision, besides having validity and reliability confirmed by several samples (Tabachnick \& Fidell, 2007). In the case of this study, the fit indices reached by the confirmatory validation could be considered reasonable considering the high complexity of the construct.

Another limitation is the cross-sectional nature of the data. The development of a time-series database and testing in a longitudinal framework of the six-factor HRM policies and practices structure obtained here is recommended. Nevertheless, it is important to state that, in this research, samples of employees from several professional activities in organizations from different sectors were used seeking the best representativeness as possible.

Considering the limitations mentioned, continued refinement of the HRMPPS is recommended based on further research on new HRM trends and perspectives and changes in business environments, so that a valid measure of HRM policies and practices can be ensured on an ongoing basis. Therefore, there could be a need for alteration or even deletion of original items. Additionally, items disclosed and mentioned as important in literature could be present in future factor analyses, such as: in the work conditions policy, the organization can offer flexible benefits plan (cafeteria), workplace amenities and conveniences, such as banks, snack bars, among others, exercise programs in the workplace, and other leisure and health benefits; prioritizing internal recruitment over external in the recruitment and selection policy; and the existence of internal communication channels in the involvement policy.

Finally, the findings found here are not intended to be conclusive or limiting but offer a useful starting point from which further theoretical and empirical research on HRM policies and practices can be built.

\section{Received 4 November 2011; received in revised form 31 July 2012.}

\section{References}

ALDamoe, F. M. A., Yazam, M., \& Ahmid, K. B. (2012). The mediating effect of HRM outcomes (employee retention) on the relationship between HRM practices and organizational performance. International Journal of Human Resource Studies, 2(1), 75-88. doi: 10.5296/ijhrs.v2i1.1252

Armstrong, M. (2009). Armstrong's handbook of human resource management practice (11th ed.). London: Kogan Page.

Baptiste, N. R. (2008). Tightening the link between employee wellbeing at work and performance: a new dimension for HRM. Management Decision, 46(2), 284-309. doi: $10.1108 / 00251740810854168$

Bardin, L. (2011). Análise de conteúdo. Lisboa: Edições 70.

Barney, J. (1991). Firm resources and sustained competitive advantage. Journal of Management, 17(1), 99-120. doi: 10.1177/014920639101700108

Beauvallet, G., \& Houy, T. (2010). Research on HRM and lean management: a literature survey. International Journal of Human Resources Development and Management, 10(1), 14-33. doi: 10.1504/IJHRDM.2010.029444

Bohlander, G. W., \& Snell, S. (2009). Administração de recursos humanos (14th ed.). São Paulo: Cengage. 
Borges-Andrade, J. E., Abbad, G., \& Mourão, L. (2006). Treinamento, desenvolvimento e educação em organizações de trabalho. Porto Alegre: Artmed.

Boselie, P., Dietz, G., \& Boon, C. (2005). Comunalities and contradictions in HRM and performance research. Human Resource Management Journal, 15(3), 67-94. doi: 10.1111/j.17488583.2005.tb00154.x

Boxall, P., \& Purcell, J. (2000). Strategic human resource management: where have we come from e where should we be going? International Journal of Management Reviews, 2(2) 183-203. doi: $10.1111 / 1468-2370.00037$

Byrne, B. M. (2009). Structural equation modeling with AMOS: basic concepts, applications, and programming (2nd ed.). New York: Routledge.

Chênevert, D., \& Tremblay, M. (2009). Fits in strategic human resource management and methodological challenge: empirical evidence of influence of empowerment and compensation practices on human resource performance in Canadian firms. The International Journal of Human Resource Management, 20(4), 738-770. doi: 10.1080/09585190902770547

Chin, W. W. (1998). The partial least squares approach for structural equation modeling. In G. A. Marcoulides (Ed.), Modern methods for business research (pp. 295-236). London: Lawrence Erlbaum Associates.

Combs, J., Liu Y., Hall, A., \& Ketchen, D. (2006). How much do high-performance work practices matter? A meta-analysis of their effects on organizational performance. Personnel Psychology, 59(3), 501-528. doi: 10.1111/j.1744-6570.2006.00045.x

Comrey, A. L., \& Lee, H. B. (1992). A first course in factor analysis (2nd ed.). Hillsdale, New Jersey: Lawrence Erlbaum Associates.

Demo, G. (2008). Desenvolvimento e validação da escala de percepção de políticas de gestão de pessoas (EPPGP). Revista de Administração Mackenzie, 9(6), 77-101. doi: 10.1590/S167869712008000600005

Demo, G. (2010). Políticas de gestão de pessoas, valores pessoais e justiça organizacional. Revista de Administração Mackenzie, 11(5), 55-81. doi: 10.1590/S1678-69712010000500004

Dessler, G. (2002). Human resource management (9th ed.). New Jersey: Prentice Hall.

Devanna, M. A., Fombrun, C. J., \& Tichy, N. M. (1984). Strategic human resource management. New York: John Wiley and Sons.

Dietz, G., Wilkinson, A., \& Redman, T. (2010). Involvement and participation. In A. Wilkinson, N. Bacon, T. Redman, \& S. Snell (Eds.), The SAGE handbook of human resource management (pp. 245-268). London: Sage.

Dutra, J. S. (2001). Gestão por competências (5th ed.). São Paulo: Editora Gente.

Ezzamel, M., Lilley, S., \& Willmott, H (1996). Practices and practicalities in human resource management. Human Resource Management Journal, 6(1), 63-80. doi: 10.1111/j.17488583.1996.tb00397.x

Frenkel, S., Restubog, S. L. D., \& Bednall, T. (2012). How employee perceptions of HR policy and practice influence discretionary work effort and co-worker assistance: evidence from two organizations. The International Journal of Human Resource Management, 23(20), 4193-4210. doi: 10.1080/09585192.2012.667433

Field, A. (2009). Discovering statistics using SPSS (3rd ed.). Thousand Oaks, CA: Sage. 
Gerhart, B. (2010). Compensation. In A. Wilkinson, N. Bacon, T. Redman, S. Snell (Eds.), The SAGE handbook of human resource management (pp. 210-230). London: Sage.

Goldstein, I. L. (1996). Training in work organizations. In M. Dunnete, \& L. M. Hough (Eds.), Handbook of industrial and organizational psychology (Vol. 2, pp. 507-619). Palo Alto: Consulting Psychology Press.

Guest, D. (1987). Human resource management and industrial relations. The Journal of Management Studies, 24(5), 503-521. doi: 10.1111/j.1467-6486.1987.tb00460.x

Guest, D. (1998). Is the psychological contract worth taking seriously? Journal of Organisational Behaviour, 19(S1), 649-664. doi: 10.1002/(SICI)1099-1379(1998)19:1+<649::AIDJOB970>3.0.CO;2-T

Guest, D., \& Conway, N. (2011). The impact of HR practices, HR effectiveness and a 'strong HR system' on organisational outcomes: a stakeholder perspective. The International Journal of Human Resource Management, 22(8), 1686-1702. doi: 10.1080/09585192.2011.565657

Guest, D., \& Hoque, K. (1994). Yes, personnel does make a difference. Personnel Management, 26(11), 40-43.

Hair, J. F., Black, W. C., Babi, B. J., Anderson, R. E., \& Tatham, R. L. (2009). Análise multivariada de dados (6th ed.). Porto Alegre: Bookman.

Hipólito, J. A. M. (2001). Tendências no campo da remuneração para o novo milênio. In J. S. Dutra (Org.), Gestão por competências (5th ed., pp. 71-94). São Paulo: Gente.

Huselid, M. A. (1995). The impact of human resource management practices on turnover, productivity, and corporate financial performance. Academy of Management Journal, 38(3), 635-672.

Kaiser, H. F. (1974). An index of factorial simplicity. Psychometrika, 39(1), 31-36. doi: 10.1007/BF02291575

Katou, A. A. (2012). Investigating reverse causality between human resource management policies and organizational performance in small firms. Management Research Review, 35(2), 134-156. doi: $10.1108 / 01409171211195161$

Kerlinger, F. N., \& Lee, H. B. (2008). Foundations of behavioral research (5th ed.). Independence, KY: Wadsworth Thomson.

Kim, A., \& Lee, C. (2012). How does HRM enhance strategic capabilities? Evidence from the Korean management consulting industry. The International Journal of Human Resource Management, 23(1), 126-146. doi: 10.1080/09585192.2011.561247

Kline, R. B. (2011). Principles and practice of structural equation modeling (3rd ed.). New York: The Guilford Press.

Latham, G., Sulsky, L. M., \& Macdonald, H. (2007). Performance management. In P. Boxall, J. Purcell, \& P. Wright. (Eds.), The Oxford handbook of human resource management (pp. 364381). New York: Oxford University Press.

Legge, K. (2006). Human resource management. In S. Ackroyd, R. Batt, P. Thompson, \& P. S. Tolbert (Eds.), The Oxford handbook of work and organization (pp. 220-241). New York: Oxford University Press. 
Lievens, F., \& Chapman, D. (2010). Recruitment and selection. In A. Wilkinson, N. Bacon, T. Redman, \& S. Snell (Eds.), The SAGE handbook of human resource management (pp. 135-154). London: Sage.

Lim W. M. (2012). Organisational strategic human resource management - The case of lehman brothers. Journal of Management Research, 4(2), 1-8. doi: 10.5296/jmr.v4i2.1368

Loudoun, R., \& Johnstone, R. (2010). Occupational health and safety in the modern world of work. In A. Wilkinson, N. Bacon, T. Redman, S. Snell (Eds.), The SAGE handbook of human resource management (pp. 286-307). London: Sage.

Majumder, M. T. H. (2012). HRM practices and employees'satisfaction towards private banking sector in Bangladesh. International Review of Management and Marketing, 2(1), 52-58.

Mathis, R. L., \& Jackson, J. H. (2003). Human resource management (10th ed.). Ohio: SouthWestern/Thomson.

Menard, S. (2002). Applied logistic regression analysis. Thousand Oaks, CA: Sage.

Menezes, L. M., Wood, S., \& Gelade, G. (2010). The integration of human resource and operation management practices and its link with performance: a longitudinal latent class study. Journal of Operations Management, 28(6), 455-471. doi: 10.1016/j.jom.2010.01.002

Morris, S., \& Snell, S. (2010). The evolution of HR strategy: adaptations to increasing global complexity. In A. Wilkinson, N. Bacon, T. Redman, S. Snell (Eds.), The SAGE handbook of human resource management (pp. 84-99). London: Sage.

Muckinsky, P. M. (2004). Psicologia organizacional. São Paulo: Pioneira Thomson Learning.

Myers, R. (1990). Classical and modern regression with applications (2nd ed.). Boston, MA: Duxbury.

Nishii, L. H., Lepak, D. P., \& Schneider, B. (2008). Employee attributions of the "Why" of HR practices: their effects on employee attitudes and behaviors, and customer satisfaction. Personnel Psychology, 61(3), 503-545. doi: 10.1111/j.1744-6570.2008.00121.x

Nunnally, J. C., \& Bernstein, I. H. (1994). Psychometric theory (3rd ed.). New York: McGraw-Hill.

Osborn, R., Hunt, J., \& Schermerhorn, J. (1998). Fundamentos de comportamento organizacional (2nd ed.). São Paulo: Bookman.

Pasquali, L. (Org.). (2008). Instrumentos psicológicos: manual prático de elaboração (2nd ed.). Brasília: LabPAM-IBAPP.

Peterson, R. A. (1994). A meta-analysis of Cronbach's coefficient alpha. Journal of Consumer Research, 21(2), 381-391.

Pfeffer, J. (2005). Producing sustainable competitive advantage through effective management of people. Academy of Management Executive, 19(4), 95-108.

Rubino, T., Demo, G., \& Traldi, M. T. F. (2011, April). As políticas de gestão de pessoas influenciam o bem-estar no trabalho? Proceedings of the Congresso Iberoamericano de Psicologia das Organizações e do Trabalho, Florianópolis, SC, Brazil, 2.

Schneider, B., \& Bowen, D. (1985). Employee and customer perceptions of service in banks: replication and extension. Journal of Applied Psychology, 70(3), 423-433. doi: 10.1037/00219010.70 .3 .423 
Serpell, A., \& Ferrada, X. (2007). A competency-based model for construction supervisors in developing countries. Personnel Review, 36(4), 585-602. doi: 10.1108/00483480710752812

Singar, E. J., \& Ramdsen, J. (1972). Human resources: obtaining results from people at work. UK: McGraw-Hill.

Siqueira, M. M. M. (2008). Envolvimento com o trabalho. In M. M. M. Siqueira (Org.), Medidas do comportamento organizacional: ferramentas de diagnóstico e de gestão (pp. 139-143). Porto Alegre: Artmed.

Sisson, K. (1994). Personnel management: paradigms, practice and prospects. In: K. Sisson (Ed.), Personnel management (2nd ed., pp. 3-50). Oxford: Blackwell.

Stone, D. L., Stone-Romero, E. F., \& Lukaszewski, K. (2007). The impact of cultural values on acceptance and effectiveness of human resource management policies and practices. Human Resource Management Review, 17(2), 152-165. doi: 10.1016/j.hrmr.2007.04.003

Storey, J. (1995). New perspectives in human resource management. London: Routledge.

Subramony, M. (2009). A meta-analytic investigation of the relationship between HRM bundles and firm performance. Human Resource Management, 48(5), 745-768. doi: 10.1002/hrm.20315

Tabachnick, B. G., \& Fidell, L. S. (2007). Using multivariate statistics (5th ed.). San Francisco: Allyn \& Bacon.

Turner, R., Huemann, M., \& Keegan, A. (2008). Human resource management in the project-oriented organization: employee well-being and ethical treatment. The International Journal of Project Management, 26(5), 577-585. doi: 10.1016/j.ijproman.2008.05.005

Ulrich, D. (2001). Os campeões de recursos humanos. São Paulo: Futura.

Ulrich, D., Halbrook, R., Meder, D., Stuchlik, M., \& Thorpe, S. (1991). Employee and customer attachment: synergies for competitive. Human Resource Planning, 14(2), 89-102.

Uysal, G. (2012). For the development of effective HRM systems: inter-relationships between HRM practices using correlation analysis. World Review of Entrepreneurship, Management and Sustainable Development, 8(1), 1-12. doi: 10.1504/WREMSD.2012.044483

Vakola, M., Soderquist, K. E., \& Pratascos, G. P. (2007). Competence management in support of organizational change. International Journal of Manpower, 28(3/4), 260-275. doi: $10.1108 / 01437720710755245$

Winterton, J. (2007). Training, development and competence. In P. Boxall, J. Purcell, \& P. Wright (Eds.), The Oxford handbook of human resource management (pp. 324-343). New York: Oxford University Press. 